\title{
Exhumation and tectonic unroofing of late Miocene granites in Elba, Italy
}

\author{
MEINERT K.W. RAHN ${ }^{1}$, ALEXIS DERYCKE ${ }^{2}$, CÉCILE E \\ GAUTHERON $^{3}$ AND PIERRE VALLA $^{4}$
}

${ }^{1}$ Swiss Federal Nuclear Safety Inspectorate ENSI

${ }^{2}$ Université Paris-Saclay

${ }^{3}$ Université Paris Saclay, CNRS

${ }^{4}$ University of Bern

Presenting Author: meinert.rahn@unibas.ch

The geologic pattern of Elba island is strongly shaped by Miocene magmatic activity, providing a suite of intrusive bodies with an age range from 8.5 to $5.9 \mathrm{Ma}$ (Dini et al. 2002, Maineri et al. 2003). While in western Elba, the roof of the Monte Capanne intrusions (ca. $7 \mathrm{Ma}$, Dini et al. 2002) has been exhumed to more than $1 \mathrm{~km}$ above sea level, the top of the eastern Porto Azzurro intrusion (5.9 Ma, Maineri et al. 2003) has remained at near-sea level, but is associated to several Fe ore bodies dated to 5.4 Ma (Lippolt et al. 1994, Wu et al. 2018). During progressive exhumation of the Monte Capanne intrusions, three main normal faults were formed, next to the eastern rim of the intrusion (Eastern border fault), with a throw of 2-3 km (Westerman et al. 2015), in the central area of the island (Central Elba fault) and towards the east (Zuccale fault, Maineri et al. 2003). Normal faulting of the last-mentioned fault crosscuts geothermally altered rocks and ore formations, providing qualitative constraints on the timing of fault activity. In a preliminary study Bouillin et al. (1994) presented apatite fission track (AFT) ages from the Monte Capanne intrusions, with linearly increasing ages from 3.6 (coastline) to $5.4 \mathrm{Ma}$ (Monte Capanne summit), suggesting that AFT ages reflect constant post-emplacement cooling/exhumation.

In this report, new AFT and (U-Th)/He (AHe) ages from both the western and eastern intrusions are presented. AFT ages from the Monte Capanne pluton are similar to those in Bouillin et al. (1994), ranging from 4.4 to $6.2 \mathrm{Ma}$. The ages suggest fast exhumation shortly after granite emplacement, as also indicated by relatively long AFT lengths (means of 14.6 to $15.3 \mu \mathrm{m}$ ). AFT ages from the eastern Porto Azzurro intrusions range from 4.4 to $5.0 \mathrm{Ma}$, with mean track lengths of 14.6 to $14.8 \mu \mathrm{m}$. In contrast, AHe ages for all dated samples are systematically older than AFT ages, with no systematic trend between AFT and AHe ages or any age-elevation relationship. The deviating behaviour of AFT and AHe data are used to test different exhumation process hypotheses. 